\title{
Variation of glucoraphanin and glucobrassicin: anticancer components in Brassica during processing
}

\author{
Me-Hea PARK ${ }^{1}$, Mariadhas VALAN ARASU², No-Young PARK ${ }^{2}$, Yun-Jong CHOI ${ }^{2}$, \\ Sang-Won LEE ${ }^{3}$, Naif Abdullah AL-DHABI ${ }^{4}$, Jung Bong KIM ${ }^{5 *}$, Sun-Ju KIM ${ }^{2 *}$
}

\begin{abstract}
Effects of cold storage and three common cooking practices, blanching, sauteing, and microwave cooking at different time intervals, on the content of glucosinolate (GSL) anticancer components in six Brassica vegetables were investigated. Eleven GSLs including progoitrin, glucoraphanin, sinigrin, glucoalyssin, gluconapin, glucobrassicanapin, glucoerucin, glucobrassicin, 4-methoxyglucobrassicin, gluconasturtiin, and neoglucobrassicin were quantified using LC-MS and HPLC. Storage at $4{ }^{\circ} \mathrm{C}$ indicated no significant loss of GSLs in broccoli, kohlrabi, and cabbage, and approximately $90-100 \%$ of the total concentration of aliphatic and indolyl GSLs were detected. Interestingly, glucoraphanin and glucobrassicin, known as a cancer prevention agents, increased approximately above $50 \%$ in broccoli, kohlrabi, and cabbage, while the amount of glucobrassicin decreased by $5 \%$ in cauliflower for 5 days at $4{ }^{\circ} \mathrm{C}$. Blanching of broccoli at $120 \mathrm{sec}$ significantly (36\%) decreased total GSLs; however, sautéing and microwaving decreased by $13-26 \%$. Individual GSLs have different response at blanching. These findings suggest that different processing methods for each vegetable would be preferred to preserve the nutritional qualities.
\end{abstract}

Keywords: Brassica vegetables; glucosinolates; storage; cooking.

\section{Introduction}

Brassica vegetables have widely been grown in Europe, Korea, Japan, and China for at least 600 years and in North America since the early 20th century (HORN, 1985). Consumption of Brassica vegetables as food has been increased because of their relatively high protein content and high dry matter digestibility and also because of their role in prevention of cancer (LI et al., 2010). Among Brassica vegetables, broccoli (Brassica oleracea var. italica), cabbage (B. oleracea var. capitata), cauliflower (B. oleracea var. botrytis), and kale (B. oleracea var. acephala), stand out as good sources of phytochemicals such as glucosinolates (GSLs), vitamins, carotenoids, and polyphenols. These vegetables are differentiated from other plants by their high GSL contents (CARTEA; VELASCO, 2008). GSLs, known as mustard oil glucosides, are a class of nitrogen and sulphurcontaining natural products distributed in 16 dicotyledonous families of the order Capparales and are mostly clustered within the Brassicaceae (VERKERK et al., 2009). The anti-carcinogenic properties of Brassica vegetables have mainly been attributed to the hydrolytic products rather than to the intact GSLs (Figure 1). Most hydrolysis products from glucoiberin, sinigrin, and progoitrin have anticancer effects. This chemo-preventive activity of Brassica vegetables is related to the amount of GSLs, their conversion to isothiocyanates, bioavailability, and stability of the isothiocyanate metabolites.
Brassica vegetables are normally purchased from local stores or obtained from farms and stored at $4-8{ }^{\circ} \mathrm{C}$ in a refrigerator or at ambient temperature for up to a week. Storage and cooking process of Brassica vegetables commonly consumed daily by humans affect the GSL arrangement and related isothiocyanate content (JIA et al., 2009). GSLs are chemically stable until they come in contact with the enzyme myrosinase, which is stored compartmentalized, separated from GSLs in the plant tissue (KELLY; BONES; ROSSITER, 1998). They become accessible to myrosinase when the plant tissue is disrupted, such as in insect predation, or when vegetables are frozen and thawed, chopped, and shredded in preparation for cooking (VERKERK; DEKKER; JONGEN, 2001). Domestic treatments including chopping, cooking, steaming, and microwaving have wide impact on GSL content, while the effects of industrial processes such as freezing, fermenting, and hot packing have little effect (DEKKER; VERKERK; JONGEN, 2000). During heating, GSL levels are reduced by enzymatic breakdown, thermal breakdown, and leak into the hot medium. Thermal breakdown of synthetic glucobrassicin results in $10 \%$ degradation and leads to the formation of a new breakdown product, 2-(30-indolylmethyl) glucobrassicin, after heating at $100^{\circ} \mathrm{C}$ for 1 hour (CHEVOLLEAU et al., 2002). Microwaving is an efficient choice for cooking vegetables due to the low amount of cooking

Received 2/6/2013

Accepted 8/4/2013 (006012)

Department of Horticultural Crop Research, National Institute of Horticultural and Herbal Science - NIHHS, Rural Development Administration - RDA, 475 Imok-Dong, Jangan-Gu, Suwon 440-706, Republic of Korea

2 Department of Bio-Environmental Chemistry, College of Agriculture and Life Sciences, Chungnam National University - CNU, Daejeon 305-764, Republic of Korea, e-mail: kimsunju@cnu.ac.kr

${ }^{3}$ Herbal Crop Utilization Research Team, National Institute of Horticultural and Herbal Science - NIHHS, Rural Development Administration - RDA, Eumseong-Gun, Chungcheongbuk-Do 369-873, Republic of Korea

${ }^{4}$ Department of Botany and Microbiology, Addiriyah Chair for Environmental Studies, College of Science, King Saud University - KSU, Riyadh 11451, Saudi Arabia

5 Food Nutrition \& Functionality Division National Academy of Agricultural Science - NAAS, Rural Development Administration - RDA, 88-2 Sedun-Dong, Suwon 441-100, Republic of Korea, e-mail: jungbkim@korea.kr

${ }^{*}$ Corresponding author 


\section{Glucosinolates}
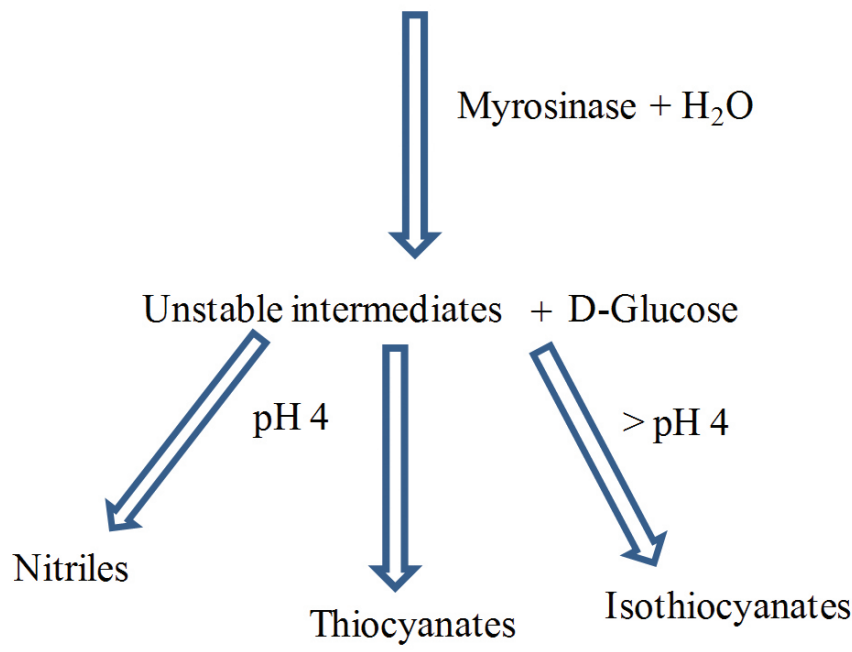

Figure 1. Glucosinolates and their degradation products.

water requirement. An earlier investigation revealed that the content of GSLs decreased after canning. Brassica vegetables are not always consumed raw; they are often subjected to processing. However, it is not clear how the amount of individual GSLs in Brassica vegetables is changed by different processing methods. The purpose of the present study was to investigate the effects of three common domestic cooking methods (blanching, sautéing, and microwaving) on the content of GSL and the effect of storage on the GSL content of broccoli, cauliflower, kohlrabi (white and red), and cabbage (white and red).

\section{Materials and methods}

\subsection{Chemicals}

HPLC-grade acetonitrile $\left(\mathrm{CH}_{3} \mathrm{CN}\right)$ and methanol $(\mathrm{MeOH})$ were purchased from J. T. Baker Chemical Co. (Phillipsburg, NJ, USA) and sodium acetate $\left(\mathrm{NaC}_{2} \mathrm{H}_{3} \mathrm{O}_{2} \cdot 3 \mathrm{H}_{2} \mathrm{O}\right)$ from Hayashi Pure Chemical Industries, Ltd. (Osaka, Japan). DEAE-Sephadex A-25 and Aryl sulfatase (type H-1, EC 3.1.6.1) were obtained from Sigma-Aldrich (St Louis, MO, USA). Standard sinigrin (2-propenyl GSL) (purity 99\%) was purchased from SigmaAldrich (St Louis, MO, USA).

\subsection{Plant materials}

Freshly harvested broccoli, cauliflower, white and red kohlrabi, and white and red cabbage originally cultivated in the Jeju Island, Republic of Korea, were purchased from a local market, the Agricultural and Fish Market. They were free from insect and mechanical damage. The vegetables were transported to the laboratory within 30 minutes of purchasing and stored at $4^{\circ} \mathrm{C}$ until chemical analysis. Fresh broccoli and cauliflower were cleaned by removing of inedible parts and then chopped into homogeneous pieces leaving a stem of about $5 \mathrm{~cm}$. The outer leaves of cabbage and kohlrabi were trimmed. To obtain more homogeneous samples, each batch was then properly divided into $>10$ equal portions. One portion was retained raw, and the others were prepared using different cooking methods, in triplicate, as given below.

\subsection{Effect of storage}

Effect of storage on the GSL contents was evaluated by storing vegetables up to 10 days at $4{ }^{\circ} \mathrm{C}$ in the vegetable compartment of a domestic refrigerator (Samsung Electronics Co. Ltd., Korea). Individual GSL contents were analyzed at $0,1,3$, and 5 days for broccoli and cauliflower, respectively, and at $0,1,3,6$, and 10 days for kohlrabi and cabbage.

\subsection{Heat treatment of vegetables}

For blanching, fresh raw vegetables were added individually to boiling tap water in a covered stainless steel pot $\left(1000 \mathrm{~cm}^{3}\right)$ and cooked on a moderate flame for 30, 90, and $120 \mathrm{sec}$. Cooking time was measured from the time the samples were placed into the boiling water; the vegetables were boiled and subsequently drained off for $30 \mathrm{sec}$.

For studies of sautéing by stir-frying, a non-stick pan was used (diameter of $25 \mathrm{~cm}$; depth of $5 \mathrm{~cm}$ ). An aliquot $(20 \% \mathrm{w} / \mathrm{w}$ of fresh vegetable) of soybean cooking oil was preheated to $200^{\circ} \mathrm{C}$. Fresh vegetable were sliced into $1 \mathrm{~cm}$ strips immediately beforehand, added to the oil, and stir-fried for $90 \mathrm{sec}$ with repeated stirring using a wood stick during cooking. The temperature of the oil decreased to $100-130^{\circ} \mathrm{C}$ with the addition of the vegetables, and it was maintained at this temperature during cooking. After cooking, the vegetables were taken out, cooled to room temperature, and analyzed for GSLs.

Microwave cooking treatments were carried out using a domestic microwave oven (Samsung Electronics Co. Ltd., Korea) without water. The microwave oven was operated at a frequency of $2450 \mathrm{~Hz}$ at power $(800 \mathrm{~W})$. Fresh broccoli was cooked for $90 \mathrm{sec}$.

\subsection{Extraction of crude glucosinolates and their desulphation}

Crude glucosinolates were extracted according to the Official Procedure ISO 9167 (INTERNATIONAL..., 1992), as described earlier by Kim, Jin, Ishii (2004). Briefly, $100 \mathrm{mg}$ of freeze-dried materials were extracted with $1.5 \mathrm{ml}$ of boiling $70 \%(\mathrm{v} / \mathrm{v})$ methanol in a water bath at $70^{\circ} \mathrm{C}$ for 5 minutes. After centrifugation $\left(12,000 \mathrm{rpm}, 4^{\circ} \mathrm{C}, 10\right.$ minutes), the resulting supernatant was collected, and the residue was extracted twice. The combined supernatant was taken as the crude of GSLs. Desulphation of the crude GSL extracts was performed using a DEAE anion exchange column, which was prepared by adding slurry of DEAE Sephadex A-25 previously activated with $0.5 \mathrm{M}$ sodium acetate. Five $\mathrm{ml}$ of sinigrin solution $(0.1 \mathrm{mg} / \mathrm{ml})$, used as an external standard, was separately desulphated using the same DEAE anion exchange column. The crude GSL extracts were loaded onto a pre-equilibrated DEAE anion exchange column. After washing with $1 \mathrm{ml}$ ( $\times 3$ times) of ultrapure water to remove cation and neutral ions, $75 \mu \mathrm{l}$ of aryl sulfatase (E.C.3.1.6.1) were then loaded onto each column. After desulphation reaction overnight (16-18 hours) at room temperature, the desulphated 
GSLs were eluted with $0.5 \mathrm{ml}$ ( $\times 3$ times) of distilled water. The eluates were filtered through $0.45 \mu \mathrm{m}$ Teflon PTFE syringe filter and analyzed immediately by HPLC or stored at $4{ }^{\circ} \mathrm{C}$ in the refrigerator until chemical analysis.

\subsection{Separation and identification of desulpho (DS)- glucosinolates using HPLC and LC-MS}

DS-GSLs were analyzed by a 1200 series HPLC system (Agilent Technologies, CA, USA) equipped with an Inertsil ODS-3 (C18) column $(150 \times 3.0 \mathrm{~mm}$ i.d., $3 \mu \mathrm{m}$ particle size $)$ (GL Science, Tokyo, Japan). The HPLC analysis was carried out with a flow rate of $0.2 \mathrm{ml} \mathrm{min}^{-1}$ at column oven temperature of $40{ }^{\circ} \mathrm{C}$ and a wavelength of $227 \mathrm{~nm}$. The solvent system employed was (A) ultrapure water (PURELAB Option-Q, ELGA) and (B) $100 \%$ acetonitrile. The solvent program was as follows: 0 minute solvent B 7\%, 18 minutes solvent B 24\%, then kept constant at solvent B $24 \%$ by 32 minutes, further solvent B $7 \%$ at 32.1 minutes, and then kept constant at solvent B 7\% for 10 minutes (total 40 minutes). The individual GSLs were quantified with sinigrin solution according to their HPLC area and response factor (INTERNATIONAL..., 1992; CLARKE, 2010). In this study, all the DS-GSLs were determined as GSLs.

Electrospray ionization (ESI)- mass spectrometry was used for the identification of individual DS-GSLs with an API 4000 Q TRAP system (Applied Biosystems, Foster City, CA, USA) in positive ion mode $\left([\mathrm{M}+\mathrm{H}]^{+}\right)$that was equipped with an Agilent 1200 series HPLC system. The MS operating conditions were as follows: scan range, $\mathrm{m} / \mathrm{z}$ 100-800 (scan time, $1.0 \mathrm{sec}$ ); curtain gas (20 psi), nebulizing gas (50 psi), heating gas (50 psi) by high purity nitrogen $\left(\mathrm{N}_{2}\right)$; heating gas temperature, $550{ }^{\circ} \mathrm{C}$; ion spray voltage, $5,500 \mathrm{~V}$; declustering potential, $100 \mathrm{~V}$; and entrance potential, $10 \mathrm{~V}$.

\subsection{Statistical analysis}

GSLs were analyzed with three replications. The mean and standard deviation of all data were calculated in Excel 2007.

\section{Results and discussion}

\subsection{Identification of individual glucosinolates}

In this study, 11 GSLs of all cruciferous vegetables were tentatively identified by LC-MS/MS. The molecular ion and fragmentation patterns of MS spectra were in accordance with the data found in the literature and allowed for unequivocal identification of GSLs (BARBIERI et al., 2008). The identified GSLs were quantified against the external standard (sinigrin) using relative response factors derived from pure GSL standards (INTERNATIONAL..., 1992; CLARKE, 2010). The response factors used are shown in Table 1 with respect to the commercially available sinigrin. The identified GSLs response factors varied 5.8 fold. Glucobrassicanapin shared the highest values (1.15), and neoglucobrassicin had the lowest value (0.2). In general, modifications of the side chain by elongation, oxidation of the parent thiol function, or alkene formation had little effect on the response factor. Seven aliphatic GSLs (progoitrin, glucoraphanin, sinigrin, glucoalyssin, gluconapin, glucobrassicanapin, and glucoerucin), three indolyl GSLs (glucobrassicin, 4-methoxyglucobrassicin, and neoglucobrassicin), and one aromatic GSL (gluconasturtiin) were identified based on the fragmentation patterns of MS spectrum and quantified based on the retention times of HPLC chromatograms (Table 1, Figure 2). These findings were in agreement with those of other research groups claiming that glucoraphanin, sinigrin, glucobrassicin, and neoglucobrassicin were commonly found in cabbage varieties (CARTEA et al., 2008).

\subsection{Effect of storage periods}

The three most abundant GSLs (glucoraphanin, glucoerucin, and gluconapin) were found in the broccoli on the first day of storage (0) (Table 2). In a previous study, we reported that the predominant GSL in Brassica crops was gluconapin, which represents $51 \%$ and $77 \%$ of total GSL and total aliphatic contents, respectively (KIM et al., 2002). Interestingly, after 5 days of storage, glucoraphanin and glucobrassicin contents in broccoli increased 68 and 31\%, respectively.

Table 1. Identification of glucosinolates from Brassica vegetables.

\begin{tabular}{|c|c|c|c|c|c|c|}
\hline No. ${ }^{\text {a) }}$ & $\begin{array}{l}\text { Retention } \\
\text { time (min) }\end{array}$ & Trivial names & Semisystemic names of $\mathbf{R}$-group & Structures of $\mathbf{R}$-group & $\begin{array}{c}\text { Molecular } \\
\text { weight }^{\text {b) }}\end{array}$ & $\begin{array}{l}\text { Response } \\
\text { factors }^{c)}\end{array}$ \\
\hline 1 & 5.39 & Progoitrin & 2-Hydroxy-3-butenyl & $\mathrm{CH}_{2}=\mathrm{CHCH}(\mathrm{OH}) \mathrm{CH}_{2}-$ & 309 & 1.09 \\
\hline 2 & 6.18 & Glucoraphanin & 4-Methylsulfinylbutyl & $\mathrm{CH}_{3}-\mathrm{SO}-\left(\mathrm{CH}_{2}\right)_{4}^{-}$ & 357 & 1.07 \\
\hline 3 & 7.75 & Sinigrin & 2-Propenyl & $\mathrm{CH}_{2}=\mathrm{CHCH}_{2}^{-}$ & 279 & 1.00 \\
\hline 4 & 8.74 & Glucoalyssin & 5-Methylsufinylpentyl & $\mathrm{CH}_{3}-\mathrm{SO}-\left(\mathrm{CH}_{2}\right)_{5}^{-}$ & 371 & 1.07 \\
\hline 5 & 14.23 & Gluconapin & 3-Butenyl & $\mathrm{CH}_{2}=\mathrm{CH}-\left(\mathrm{CH}_{2}\right)_{2}-$ & 293 & 1.11 \\
\hline 6 & 16.24 & Glucobrassicanapin & 4-Pentenyl & $\mathrm{CH}_{2}=\mathrm{CH}_{2}-\left(\mathrm{CH}_{2}\right)_{3}-$ & 307 & 1.15 \\
\hline 7 & 20.78 & Glucoerucin & 4-Methylthiobutyl & $\mathrm{CH}_{3}-\mathrm{S}-\left(\mathrm{CH}_{2}\right)_{4}$ & 341 & $1.04^{\mathrm{d})}$ \\
\hline 8 & 22.79 & Glucobrassicin & 3-Indolymethyl & Indole-3- $\mathrm{CH}_{2}-$ & 368 & 0.29 \\
\hline 9 & 25.23 & 4-Methoxyglucobrassicin & 4-Methoxy-3-indolylmethyl & Indole-4- $\mathrm{OCH}_{3}-$ & 398 & 0.25 \\
\hline 10 & 26.22 & Gluconasturtiin & 2-Phenylethyl & $\mathrm{C}_{6} \mathrm{H}_{5}-\left(\mathrm{CH}_{2}\right)_{2}^{-}$ & 343 & 0.95 \\
\hline 11 & 31.09 & Neoglucobrassicin & 1-Methoxy-3-indolylmethyl & Indole-1- $\mathrm{OCH}_{3}-$ & 398 & 0.20 \\
\hline
\end{tabular}

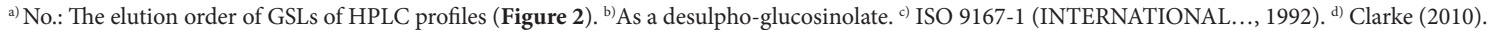



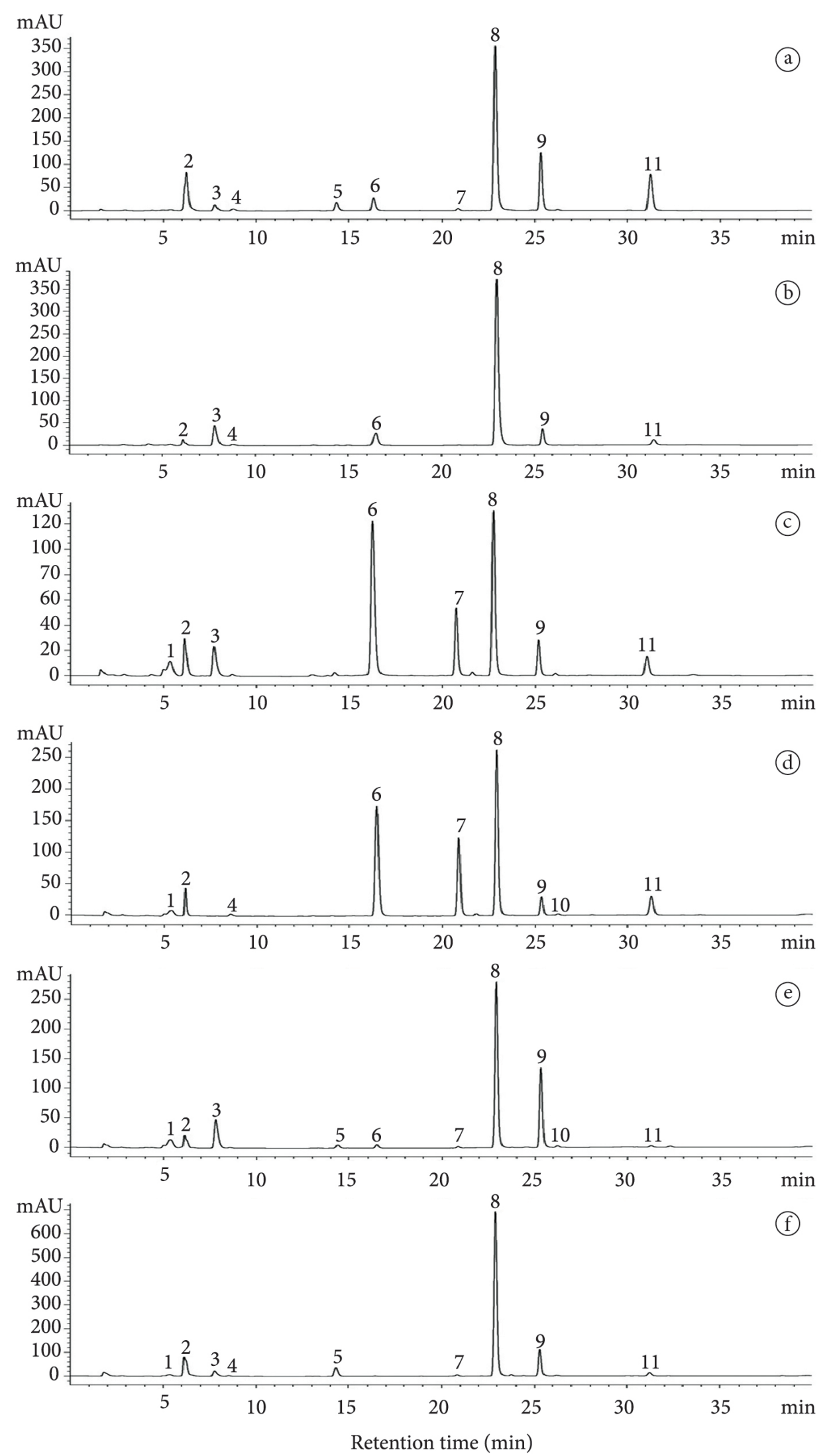

Figure 2. HPLC profiles of desulpho-glucosinolates isolated from cruciferous vegetables. (a), broccoli; (b), cauliflower; (c), white kohlrabi; (d), red kohlrabi; (e), white cabbage; (f), red cabbage. Peak numbers refer to the GSLs listed in Table 1. Peak 1, Progoitrin; 2, Glucoraphanin; 3, Sinigrin; 4, Glucoalyssin; 5, Gluconapin; 6, Glucobrassicanapin; 7, Glucoerucin; 8, Glucobrassicin; 9, 4-Methoxyglucobrassicin; 10, Gluconasturtiin; 11, Neoglucobrassicin. 
The storage period affected the content of selected GSL in cauliflower to a different extent. The changes in the amount of main GSL, such as sinigrin, gluconapin, and glucoerucin, irrespective of the time of storage, did not exceed $10 \%$. Individual GSL contents of cauliflower showed a significant decrease in sinigrin and gluconapin after 5 days of storage. Similarly, Jeffery et al. (2003) reported that indolyl GSLs were more sensitive to storage conditions than the aliphatic or aromatic GSLs.

The content of GSLs in raw white kohlrabi, red kohlrabi, white cabbage, and red cabbage were determined (Table 3 and 4). The highest total content of the GSLs was found in white cabbage approximately $61.76 \mu \mathrm{mol} / \mathrm{g}$ dry weight (DW) and lowest in white kohlrabi $16.72 \mu \mathrm{mol} / \mathrm{g}$ DW. Glucoraphanin and glucoerucin were the major GSLs in kohlrabi 32.04 and 8.10 $\mu \mathrm{mol} / \mathrm{g}$ DW, with lower contents than those of the other GSLs. After 5-10 days of storage at $4{ }^{\circ} \mathrm{C}$, a sharp increase in GSL content was observed in kohlrabi and cabbage with significant changes $16-18 \%$ in total GSL levels (Table 3 and 4 ). An increase of $100 \%$ in the total aliphatic GSLs and 90\% in total indolyl GSLs was detected. After storage for 3 days, total GSL content increased $38 \%$ in white cabbage. For individual GSLs in white cabbage, the losses of glucoraphanin, sinigrin, and glucobrassicanapin were higher than that of progoitrin, glucoerucin, and glucobrassicin.

When stored at $4{ }^{\circ} \mathrm{C}$, there was no significant decrease in the GSL content of the Brassica vegetables studied. In contrast, the total and individual GSL contents increased proportionally during storage for 10 days. Some of the GSLs showed significant loss after 5 days. Similarly, glucoraphanin and glucoiberin contents increased $25 \%$ for broccoli stored at $10^{\circ} \mathrm{C}$ for 7 days (HANSEN et al., 1997). Storage of vegetables at $4{ }^{\circ} \mathrm{C}$ may cause a significant increase of GSLs due to secondary metabolite synthesis in plant cells sentence. Humidity is known as a critical factor in GSL retention and increment when postharvest temperatures rise or are kept at approximately $4{ }^{\circ} \mathrm{C}$. Based on the results obtained, it can be stated that extended storage of vegetables causes a successive increase in the GSL content, which is more intense within the first three days of storage. Storage at $4{ }^{\circ} \mathrm{C}$ indicated no significant loss of GSLs in broccoli, kohlrabi, and cabbage; however, an increase of $100 \%$ in the total aliphatic and indolyl GSLs was observed. It is suggested that the storage of broccoli, kohlrabi, and cabbage for a short period of about 10 days did not change the GSL contents, while the storage of cauliflower at $4{ }^{\circ} \mathrm{C}$ is will not retain the anticancer valuable

Table 2. Glucosinolate contents ( $\mu \mathrm{mol} / \mathrm{g}$ dry wt., $n=3$ ) in broccoli and cauliflower stored at $4{ }^{\circ} \mathrm{C}$ for 5 days in the refrigerator.

\begin{tabular}{|c|c|c|c|c|c|c|c|c|}
\hline \multirow{2}{*}{ No. ${ }^{a)}$} & \multicolumn{4}{|c|}{ Broccoli } & \multicolumn{4}{|c|}{ Cauliflower } \\
\hline & $0^{\text {b) }}$ & 1 & 3 & 5 & 0 & 1 & 3 & 5 \\
\hline 1 & $0.81 \pm 0.24 \mathrm{a}$ & $1.22 \pm 0.08 \mathrm{a}$ & $0.70 \pm 0.04 \mathrm{a}$ & $1.71 \pm 0.77 \mathrm{a}$ & $0.69 \pm 0.13 a$ & $1.51 \pm 1.22 \mathrm{a}$ & $1.18 \pm 0.67 \mathrm{a}$ & $1.60 \pm 1.63 \mathrm{a}$ \\
\hline 2 & $19.05 \pm 3.18 \mathrm{a}$ & $25.99 \pm 1.51 \mathrm{a}$ & $18.63 \pm 1.42 \mathrm{a}$ & $31.95 \pm 11.56 \mathrm{a}$ & $1.97 \pm 0.42 \mathrm{a}$ & $1.76 \pm 0.61 \mathrm{a}$ & $2.20 \pm 0.39 \mathrm{a}$ & $2.50 \pm 0.46 \mathrm{a}$ \\
\hline 4 & $1.02 \pm 0.34 \mathrm{a}$ & $1.04 \pm 0.25 \mathrm{a}$ & $0.87 \pm 0.17 \mathrm{a}$ & $1.19 \pm 0.21 \mathrm{a}$ & $0.59 \pm 0.08 \mathrm{a}$ & $0.45 \pm 0.04 \mathrm{a}$ & $0.72 \pm 0.08 \mathrm{a}$ & $0.76 \pm 0.25 \mathrm{a}$ \\
\hline 5 & $3.15 \pm 0.58 \mathrm{a}$ & $3.57 \pm 1.01 \mathrm{a}$ & $3.09 \pm 0.41 \mathrm{a}$ & $3.48 \pm 1.04 \mathrm{a}$ & $\mathrm{ND}^{c)}$ & ND & ND & ND \\
\hline 8 & $19.57 \pm 3.72 \mathrm{a}$ & $21.28 \pm 1.77 \mathrm{a}$ & $21.72 \pm 1.54 \mathrm{a}$ & $25.61 \pm 5.08 \mathrm{a}$ & $22.31 \pm 9.01 \mathrm{a}$ & $18.35 \pm 10.99 \mathrm{a}$ & $25.25 \pm 8.23 \mathrm{a}$ & $21.25 \pm 11.99 \mathrm{a}$ \\
\hline 9 & $5.35 \pm 0.08 \mathrm{a}$ & $5.68 \pm 0.36 \mathrm{ab}$ & $5.96 \pm 0.45 b$ & $6.62 \pm 0.66 \mathrm{a}$ & $1.65 \pm 0.20 \mathrm{a}$ & $1.03 \pm 0.21 \mathrm{a}$ & $1.64 \pm 0.06 \mathrm{a}$ & $1.38 \pm 0.52 \mathrm{a}$ \\
\hline 10 & ND & ND & ND & ND & ND & ND & ND & ND \\
\hline 11 & $3.23 \pm 0.58 b$ & $2.93 \pm 0.09 \mathrm{~b}$ & $4.41 \pm 0.58 b$ & $6.71 \pm 1.06 \mathrm{a}$ & $0.69 \pm 0.21 \mathrm{a}$ & $1.88 \pm 0.49 \mathrm{a}$ & $1.83 \pm 1.29 \mathrm{a}$ & $1.25 \pm 0.82 \mathrm{a}$ \\
\hline Total & $61.11 \pm 4.14 b$ & $71.79 \pm 6.82 \mathrm{ab}$ & $65.35 \pm 3.17 b$ & $88.55 \pm 13.21 \mathrm{a}$ & $42.93 \pm 13.46 a$ & $35.50 \pm 11.86 a$ & $43.93 \pm 9.26 \mathrm{a}$ & $42.30 \pm 16.96 a$ \\
\hline
\end{tabular}

a) The trivial names of glucosinolates are shown in Table 1. ${ }^{\text {b) }}$ Duration of storing period (days). ${ }^{\text {c) }}$ ND, not detected.

Table 3. Glucosinolate contents ( $\mu \mathrm{mol} / \mathrm{g}$ dry wt., $n=3$ ) in white and red kohlrabi stored at $4{ }^{\circ} \mathrm{C}$ for 10 days in the refrigerator.

\begin{tabular}{|c|c|c|c|c|c|c|c|c|c|c|}
\hline \multirow{2}{*}{ No.a) } & \multicolumn{5}{|c|}{ White kohlrabi } & \multicolumn{5}{|c|}{ Red kohlrabi } \\
\hline & $0^{\mathrm{b})}$ & 1 & 3 & 6 & 10 & 0 & 1 & 3 & 6 & 10 \\
\hline 1 & $1.13 \pm 0.30 \mathrm{a}$ & $1.14 \pm 0.81 \mathrm{a}$ & $0.97 \pm 0.38 \mathrm{a}$ & $1.93 \pm 1.54 \mathrm{a}$ & $2.80 \pm 1.77 \mathrm{a}$ & $1.73 \pm 0.93 \mathrm{a}$ & $2.30 \pm 1.35 \mathrm{a}$ & $2.39 \pm 1.42 \mathrm{a}$ & $1.99 \pm 1.07 \mathrm{a}$ & $1.18 \pm 0.73 \mathrm{a}$ \\
\hline 2 & $2.11 \pm 0.65 \mathrm{a}$ & $2.32 \pm 1.33 \mathrm{a}$ & $2.40 \pm 0.24 \mathrm{a}$ & $3.21 \pm 1.93 \mathrm{a}$ & $4.39 \pm 2.36 \mathrm{a}$ & $2.14 \pm 1.59 \mathrm{a}$ & $2.55 \pm 2.21 \mathrm{a}$ & $2.55 \pm 2.13 \mathrm{a}$ & $3.47 \pm 1.53 \mathrm{a}$ & $1.61 \pm 0.57 \mathrm{a}$ \\
\hline 4 & $\mathrm{ND}^{\mathrm{c})}$ & ND & ND & ND & ND & $0.55 \pm 0.09 \mathrm{~b}$ & $0.75 \pm 0.05 \mathrm{a}$ & $0.61 \pm 0.03 \mathrm{ab}$ & $0.50 \pm 0.04 \mathrm{~b}$ & $0.48 \pm 0.06 \mathrm{~b}$ \\
\hline 5 & $\mathrm{ND}$ & ND & $\mathrm{ND}$ & $\mathrm{ND}$ & ND & ND & ND & ND & ND & ND \\
\hline 6 & $5.32 \pm 1.67 \mathrm{a}$ & $8.68 \pm 6.36 a$ & $13.10 \pm 6.88 \mathrm{a}$ & $10.80 \pm 6.17 \mathrm{a}$ & $23.00 \pm 14.24 \mathrm{a}$ & $32.04 \pm 12.30 \mathrm{a}$ & $36.46 \pm 8.70 \mathrm{a}$ & $33.41 \pm 11.72 \mathrm{a}$ & $25.85 \pm 8.47 \mathrm{a}$ & $28.42 \pm 9.23 \mathrm{a}$ \\
\hline 8 & $1.34 \pm 0.64 \mathrm{a}$ & $1.67 \pm 0.81 \mathrm{a}$ & $2.48 \pm 1.68 \mathrm{a}$ & $2.35 \pm 0.93 \mathrm{a}$ & $4.15 \pm 1.74 \mathrm{a}$ & $8.10 \pm 3.87 \mathrm{a}$ & $9.38 \pm 4.83 \mathrm{a}$ & $8.22 \pm 2.58 \mathrm{a}$ & $8.35 \pm 2.17 \mathrm{a}$ & $6.28 \pm 3.00 \mathrm{a}$ \\
\hline 9 & $0.56 \pm 0.20 \mathrm{a}$ & $0.61 \pm 0.27 \mathrm{a}$ & $0.78 \pm 0.44 \mathrm{a}$ & $0.81 \pm 0.16 \mathrm{a}$ & $1.07 \pm 0.04 \mathrm{a}$ & $0.82 \pm 0.55 \mathrm{a}$ & $0.72 \pm 0.39 \mathrm{a}$ & $0.88 \pm 0.53 \mathrm{a}$ & $1.03 \pm 0.64 \mathrm{a}$ & $0.70 \pm 0.40 \mathrm{a}$ \\
\hline 10 & ND & ND & ND & ND & ND & ND & $0.78 \pm 0.62 \mathrm{ab}$ & $1.44 \pm 1.23 \mathrm{a}$ & $0.56 \pm 0.00 \mathrm{ab}$ & $1.01 \pm 0.83 \mathrm{ab}$ \\
\hline 11 & $0.35 \pm 0.13 a$ & $0.55 \pm 0.35 \mathrm{a}$ & $0.56 \pm 0.36 \mathrm{a}$ & $0.70 \pm 0.36 \mathrm{a}$ & $0.57 \pm 0.09 \mathrm{a}$ & $0.86 \pm 0.21 \mathrm{a}$ & $0.99 \pm 0.22 \mathrm{a}$ & $1.54 \pm 0.88 \mathrm{a}$ & $1.43 \pm 0.63 \mathrm{a}$ & $1.18 \pm 0.58 \mathrm{a}$ \\
\hline Total & $16.72 \pm 3.39 \mathrm{a}$ & $21.85 \pm 13.26 \mathrm{a}$ & $27.36 \pm 9.50 \mathrm{a}$ & $30.12 \pm 15.80 \mathrm{a}$ & $48.35 \pm 27.29 \mathrm{a}$ & $53.71 \pm 14.77 \mathrm{a}$ & $63.77 \pm 16.05 \mathrm{a}$ & $59.16 \pm 16.67 \mathrm{a}$ & $54.92 \pm 21.17 \mathrm{a}$ & $50.03 \pm 16.49 \mathrm{a}$ \\
\hline
\end{tabular}

${ }^{\text {a) }}$ The trivial names of glucosinolates are shown in Table 1. ${ }^{\text {b) }}$ Duration of storing period (days). ${ }^{c}$ ND, not detected. 
nutritional compounds such as glucoraphanin. It is necessary to evaluate and quantify aliphatic GSLs (glucoraphanin, gluconapin, and glucoerucin) and indolyl GSL (glucobrassicin) because of their anticancer activity.

\subsection{Effect of cooking on glucosinolate contents}

Among the Brassica vegetables studied, broccoli and cauliflower are the best sources of anticancer agents. Cooking has been widely reported to cause a decrease in GSLs in broccoli and cauliflower, but varied results have been found (JONES; FARAGHER; WINKLER, 2006). Blanching affected the content of GSLs in broccoli and cauliflower to a different extent. Total GSL contents in the broccoli blanched for $120 \mathrm{sec}$ were significantly (36\%) decreased, whereas, in cauliflower even after $120 \mathrm{sec}$, total GSL did not change (Table 5). The levels of indolyl GSLs, glucobrassicin, and neoglucobrassicin, reduced by approximately $31-65 \%$ in both broccoli and cauliflower. The changes in the contents of main indolyl GSL glucobrassicin, except for broccoli blanched for 90-120 sec, were comparable. In the group of aliphatic GSL, the biggest changes during the first $60 \mathrm{sec}$ of blanching were observed for glucoalyssin (about
$100 \%$ ), and the smallest was observed for sinigrin (> 10\%) in cauliflower. However, the rate of the content loss of glucoalyssin was lower than that of sinigrin, which indicates higher thermoliability of sinigrin. Blanching of broccoli and cauliflower leads to inactivation of myrosinase and decomposition of thermo-labile GSL, especially indolyl GSLs. In addition, diffusion of water results in major losses of GSL during boiling. The reduction in the amount of glucobrassicin and glucobrassicanapin in broccoli was similar; however, during blanching their contents were the highest, ranging from $30-33 \%$. The contents of gluconapin and glucoerucin in cauliflower were lower ranging from $4-15 \%$ of their contents in raw cauliflower. An increase in the content of gluconasturtiin after $120 \mathrm{sec}$ of blanching with similar amounts of progoitrin may suggest that GSL can be bound to cell walls and released after deep disintegration of cell structures. Between 60 and $90 \mathrm{sec}$, the content of glucoraphanin and sinigrin increased $37 \%$ and $25 \%$, respectively. The amount of glucobrassicin and gluconasturtiin increased about $10 \%$. During the last $30 \mathrm{sec}$ of blanching, the content of glucobrassicin decreased about $3 \%$ and gluconasturtiin decreased $17 \%$. Jones, Faragher and Winkler (2006) also reported that inactivation of myrosinase in cruciferous vegetables, as an effect of boiling, may limit GSL

Table 4. Glucosinolate contents ( $\mu \mathrm{mol} / \mathrm{g}$ dry wt., $n=3)$ in white and red cabbage stored at $4{ }^{\circ} \mathrm{C}$ for 10 days in the refrigerator.

\begin{tabular}{|c|c|c|c|c|c|c|c|c|c|c|}
\hline \multirow{2}{*}{ No. ${ }^{\text {a) }}$} & \multicolumn{5}{|c|}{ White cabbage } & \multicolumn{5}{|c|}{ Red cabbage } \\
\hline & $0^{\mathrm{b})}$ & 1 & 3 & 6 & 10 & 0 & 1 & 3 & 6 & 10 \\
\hline 1 & $5.68 \pm 2.50 \mathrm{a}$ & $5.89 \pm 2.13 \mathrm{a}$ & $7.01 \pm 4.48 \mathrm{a}$ & $6.09 \pm 1.56 \mathrm{a}$ & $7.04 \pm 3.01 \mathrm{a}$ & $1.15 \pm 0.29 \mathrm{a}$ & $1.13 \pm 0.46 \mathrm{a}$ & $1.21 \pm 0.38 \mathrm{a}$ & $1.45 \pm 0.28 \mathrm{a}$ & $1.68 \pm 0.75 a$ \\
\hline 2 & $4.24 \pm 0.96 \mathrm{a}$ & $4.54 \pm 1.44 \mathrm{a}$ & $5.88 \pm 1.79 \mathrm{a}$ & $4.56 \pm 1.30 \mathrm{a}$ & $3.66 \pm 3.39 \mathrm{a}$ & $8.34 \pm 4.48 \mathrm{a}$ & $7.59 \pm 2.22 \mathrm{a}$ & $8.71 \pm 2.57 \mathrm{a}$ & $11.43 \pm 2.66 \mathrm{a}$ & $14.97 \pm 3.72 \mathrm{a}$ \\
\hline 3 & $10.55 \pm 4.34 \mathrm{a}$ & $14.92 \pm 0.97 \mathrm{a}$ & $13.37 \pm 4.79 \mathrm{a}$ & $14.17 \pm 5.52 \mathrm{a}$ & $13.00 \pm 3.97 \mathrm{a}$ & $5.57 \pm 2.08 \mathrm{a}$ & $6.55 \pm 2.02 \mathrm{a}$ & $3.17 \pm 1.32 \mathrm{a}$ & $3.90 \pm 0.90 \mathrm{a}$ & $4.45 \pm 0.80 \mathrm{a}$ \\
\hline 4 & $\mathrm{ND}^{\mathrm{c})}$ & ND & ND & ND & ND & $0.65 \pm 0.08 \mathrm{a}$ & $0.64 \pm 0.00 \mathrm{ab}$ & $0.49 \pm 0.06 \mathrm{~b}$ & ND & $0.58 \pm 0.14 \mathrm{ab}$ \\
\hline 5 & $1.01 \pm 0.44 \mathrm{a}$ & $1.37 \pm 0.23 \mathrm{a}$ & $1.59 \pm 0.31 \mathrm{a}$ & $1.34 \pm 0.50 \mathrm{a}$ & $1.17 \pm 0.31 \mathrm{a}$ & $4.86 \pm 2.51 \mathrm{a}$ & $5.65 \pm 2.29 a$ & $3.70 \pm 1.49 \mathrm{a}$ & $5.39 \pm 1.52 \mathrm{a}$ & $7.51 \pm 0.52 \mathrm{a}$ \\
\hline 6 & $1.77 \pm 0.79 a$ & $2.64 \pm 0.94 a$ & $3.01 \pm 0.43 \mathrm{a}$ & $2.68 \pm 0.90 \mathrm{a}$ & $2.67 \pm 0.74 a$ & ND & ND & ND & ND & ND \\
\hline 7 & $0.69 \pm 0.21 \mathrm{a}$ & $0.89 \pm 0.31 \mathrm{a}$ & $1.35 \pm 0.35 \mathrm{a}$ & $1.07 \pm 0.33 \mathrm{a}$ & $1.19 \pm 0.48 \mathrm{a}$ & $0.69 \pm 0.38 \mathrm{a}$ & ND & ND & $0.76 \pm 0.28 \mathrm{a}$ & $1.02 \pm 0.32 \mathrm{a}$ \\
\hline 8 & $21.45 \pm 7.27 \mathrm{ab}$ & $18.21 \pm 2.77 b$ & $30.65 \pm 4.78 \mathrm{a}$ & $19.45 \pm 2.85 \mathrm{ab}$ & $24.06 \pm 3.56 \mathrm{ab}$ & $16.47 \pm 9.81 \mathrm{a}$ & $13.15 \pm 1.42 \mathrm{a}$ & $18.44 \pm 3.50 \mathrm{a}$ & $23.70 \pm 7.35 \mathrm{a}$ & $29.10 \pm 8.21 \mathrm{a}$ \\
\hline 9 & $6.85 \pm 1.38 \mathrm{a}$ & $5.83 \pm 0.88 \mathrm{~b}$ & $9.47 \pm 0.55 \mathrm{a}$ & $6.65 \pm 0.25 b$ & $7.68 \pm 1.03 \mathrm{ab}$ & $2.11 \pm 0.80 \mathrm{a}$ & $2.36 \pm 0.48 \mathrm{a}$ & $2.08 \pm 0.33 \mathrm{a}$ & $3.00 \pm 0.64 \mathrm{a}$ & $3.60 \pm 0.79 \mathrm{a}$ \\
\hline 10 & $0.76 \pm 0.39 a$ & $1.27 \pm 0.22 \mathrm{a}$ & $1.16 \pm 0.50 \mathrm{a}$ & $1.32 \pm 0.79 \mathrm{a}$ & $1.07 \pm 0.25 \mathrm{a}$ & ND & ND & ND & ND & ND \\
\hline 11 & $0.18 \pm 0.06 \mathrm{a}$ & $0.20 \pm 0.06 \mathrm{a}$ & $0.21 \pm 0.07 \mathrm{a}$ & $0.21 \pm 0.08 \mathrm{a}$ & $0.22 \pm 0.02 \mathrm{a}$ & ND & ND & $0.28 \pm 0.08 \mathrm{ab}$ & $0.49 \pm 0.31 \mathrm{a}$ & $0.49 \pm 0.12 \mathrm{a}$ \\
\hline Total & $53.17 \pm 12.70 \mathrm{a}$ & $55.76 \pm 3.50 \mathrm{a}$ & $73.44 \pm 17.61 \mathrm{a}$ & $57.55 \pm 9.08 \mathrm{a}$ & $61.76 \pm 12.01 \mathrm{a}$ & $39.01 \pm 19.95 a$ & $36.84 \pm 8.16 a$ & $37.68 \pm 8.18 \mathrm{a}$ & $50.12 \pm 13.01 \mathrm{a}$ & $63.21 \pm 14.17 \mathrm{a}$ \\
\hline
\end{tabular}

a) The trivial names of glucosinolates are shown in Table $1 .{ }^{\text {b) }}$ Duration of storing period (days). ${ }^{\text {c) }}$ ND, not detected.

Table 5. Glucosinolate contents ( $\mu \mathrm{mol} / \mathrm{g}$ dry wt., $n=3$ ) of broccoli from difference of recipe and cauliflower by blanching time.

\begin{tabular}{|c|c|c|c|c|c|c|c|c|c|c|}
\hline \multirow{3}{*}{ No. ${ }^{\text {a) }}$} & \multicolumn{6}{|c|}{ Broccoli } & \multicolumn{4}{|c|}{ Cauliflower } \\
\hline & \multirow{2}{*}{$\begin{array}{c}\text { Before } \\
\text { cooking }^{\text {b) }}\end{array}$} & \multicolumn{3}{|c|}{ Blanching } & \multirow{2}{*}{$\begin{array}{c}\text { Sautéing } \\
(90 \mathrm{~s})\end{array}$} & \multirow{2}{*}{$\begin{array}{c}\text { Microwave } \\
\text { cooking }\end{array}$} & \multirow{2}{*}{$\begin{array}{c}\text { Before } \\
\text { cooking }\end{array}$} & \multicolumn{3}{|c|}{ Blanching } \\
\hline & & $60 \sec ^{\mathrm{d})}$ & $90 \mathrm{~s}$ & $120 \mathrm{~s}$ & & & & $60 \mathrm{~s}$ & $90 \mathrm{~s}$ & $120 \mathrm{~s}$ \\
\hline 1 & $0.81 \pm 0.24 \mathrm{a}$ & $1.32 \pm 0.23 \mathrm{a}$ & $1.36 \pm 0.45 \mathrm{a}$ & $1.24 \pm 0.37 \mathrm{a}$ & $1.09 \pm 0.22 \mathrm{a}$ & $1.52 \pm 0.38 \mathrm{a}$ & $0.69 \pm 0.13 \mathrm{a}$ & $0.93 \pm 0.40 \mathrm{a}$ & $1.21 \pm 0.98 \mathrm{a}$ & $1.10 \pm 0.75 \mathrm{a}$ \\
\hline 2 & $19.05 \pm 3.18 \mathrm{a}$ & $20.88 \pm 9.78 \mathrm{a}$ & $21.29 \pm 8.29 \mathrm{a}$ & $18.58 \pm 5.48 \mathrm{a}$ & $16.72 \pm 1.83 \mathrm{a}$ & $21.71 \pm 10.34 \mathrm{a}$ & $1.97 \pm 0.42 \mathrm{a}$ & $2.71 \pm 0.83 \mathrm{a}$ & $2.62 \pm 0.39 \mathrm{a}$ & $2.45 \pm 0.69 \mathrm{a}$ \\
\hline 3 & $2.50 \pm 0.20 \mathrm{a}$ & $2.61 \pm 0.53 \mathrm{a}$ & $2.07 \pm 0.61 \mathrm{a}$ & $2.00 \pm 0.08 \mathrm{a}$ & $2.15 \pm 0.19 \mathrm{a}$ & $2.75 \pm 0.69 \mathrm{a}$ & $8.00 \pm 2.75 \mathrm{a}$ & $8.65 \pm 3.55 \mathrm{a}$ & $10.06 \pm 4.42 \mathrm{a}$ & $9.61 \pm 3.63 a$ \\
\hline 4 & $1.02 \pm 0.34 \mathrm{a}$ & $\mathrm{ND}^{\mathrm{e})}$ & ND & ND & ND & $0.56 \pm 0.08 \mathrm{~b}$ & $0.59 \pm 0.08$ & ND & ND & ND \\
\hline 5 & $3.15 \pm 0.58 \mathrm{a}$ & $2.14 \pm 0.81 \mathrm{a}$ & $1.88 \pm 0.05 \mathrm{a}$ & $1.77 \pm 0.13 \mathrm{a}$ & $2.16 \pm 0.27 \mathrm{a}$ & $2.73 \pm 0.67 \mathrm{a}$ & ND & ND & ND & ND \\
\hline 6 & $5.80 \pm 3.42 \mathrm{a}$ & $5.19 \pm 2.01 \mathrm{a}$ & $4.13 \pm 2.14 \mathrm{a}$ & $2.65 \pm 0.71 \mathrm{a}$ & $3.10 \pm 1.20 \mathrm{a}$ & $4.69 \pm 3.99 \mathrm{a}$ & $7.24 \pm 2.32 \mathrm{a}$ & $6.22 \pm 2.58 \mathrm{a}$ & $8.16 \pm 3.77 \mathrm{a}$ & $6.17 \pm 3.45 \mathrm{a}$ \\
\hline 7 & $0.63 \pm 0.23 \mathrm{a}$ & $0.53 \pm 0.05 \mathrm{a}$ & $0.52 \pm 0.11 \mathrm{a}$ & $0.44 \pm 0.13 \mathrm{a}$ & ND & $0.49 \pm 0.16 \mathrm{a}$ & ND & ND & ND & ND \\
\hline 8 & $19.57 \pm 3.72 \mathrm{a}$ & $14.46 \pm 3.74 \mathrm{a}$ & $9.34 \pm 0.58 \mathrm{a}$ & $7.45 \pm 4.36 \mathrm{a}$ & $14.43 \pm 8.56 \mathrm{a}$ & $13.94 \pm 2.48$ & $22.31 \pm 9.01 \mathrm{a}$ & $22.14 \pm 9.51 \mathrm{a}$ & $25.01 \pm 10.18 \mathrm{a}$ & $21.61 \pm 10.31 \mathrm{a}$ \\
\hline 9 & $5.35 \pm 0.08 \mathrm{~b}$ & $5.50 \pm 0.75 \mathrm{a}$ & $4.36 \pm 0.28 \mathrm{ab}$ & $3.73 \pm 0.84 \mathrm{~b}$ & $3.85 \pm 0.20 \mathrm{~b}$ & $3.90 \pm 0.89 \mathrm{ab}$ & $1.65 \pm 0.20 \mathrm{a}$ & $1.94 \pm 0.49 a$ & $1.98 \pm 0.45 \mathrm{a}$ & $1.93 \pm 0.53 \mathrm{a}$ \\
\hline 10 & ND & ND & ND & ND & ND & ND & ND & ND & ND & ND \\
\hline 11 & $3.23 \pm 0.58 \mathrm{a}$ & $1.89 \pm 1.55 \mathrm{a}$ & $1.79 \pm 0.72 \mathrm{a}$ & $1.10 \pm 1.11 \mathrm{a}$ & $2.13 \pm 1.50 \mathrm{a}$ & $1.01 \pm 0.71 \mathrm{a}$ & $0.69 \pm 0.21 \mathrm{a}$ & $0.87 \pm 0.29 \mathrm{a}$ & $1.08 \pm 0.65 \mathrm{a}$ & $0.90 \pm 0.05 \mathrm{a}$ \\
\hline Total & $61.11 \pm 4.14 a$ & $54.36 \pm 14.65 a$ & $46.74 \pm 9.90 \mathrm{a}$ & $38.82 \pm 7.25 a$ & $45.63 \pm 7.04 a$ & $53.29 \pm 11.44 a$ & $42.93 \pm 13.46 \mathrm{a}$ & $43.46 \pm 15.62 \mathrm{a}$ & $50.12 \pm 13.25 a$ & $43.10 \pm 13.74 a$ \\
\hline
\end{tabular}

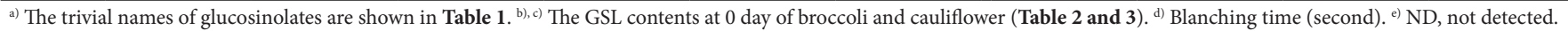


decomposition, thus resulting in consumption of GSL instead of their breakdown products by humans. In this study, most of the GSL structures present in cauliflower were tightly packed on the cell walls and were released after significant disintegration caused by the extended cooking period.

Sautéing and microwave cooking significantly reduced (1326\%) total GSL contents in broccoli, regardless of the cooking time. With regard to microwaving, there was a significant change in the total GSLs, but only slight changes in single GSL content. Similarly to the findings of Miglio et al. (2008), the total content of GSLs of fresh broccoli significantly decreased in both cooking methods, whereas it slightly changed during microwaving since the main compound (glucoraphanin) slightly increased (14\%) and indolyl GSL significantly decreased (28\%) in both cooking methods. This change in GSLs is probably justified by the lack of water in the microwaving and sautéing cooking methods, confirming that the great loss of these compounds is due to high cooking water evaporation containing leached compounds. However, the changes in the GSL content upon microwave cooking was significantly different between aliphatic and indolyl compounds. In the initial processes, myrosinase activates the degradation of GSLs to release different breakdown products. Generally, indolyl GSLs form metabolites that are inhibitors of carcinogenesis, whereas aliphatic GSL decomposes into volatile isothiocyanates, which are responsible for pungent or bitter taste. The levels of GSL do not necessarily decrease rapidly as a result of vegetable chopping and cooking and even induction can take place. The levels of indolyl GSLs and some aliphatic GSLs increased after chopping of Cruciferase vegetables. The biological activities that take place due to vegetable processing are: hydrolysis of GSLs by a hydrolytic enzyme myrosinase; loss of enzymatic cofactors such as epithiospecifier protein; thermal breakdown and/or leaching of GSLs and their metabolites or volatilization of metabolites; induction of indolyl GSLs was not confirmed (MITHEN, 2001). A hypothesis assuming that the possibility of the bounding of GSL with the cell walls as in the case of other low-molecular compounds, e.g., saccharides, glycosides, and inositol phosphates, would not be inconsistent with a theory assuming that the GSL present in the vacuole is the main reservoir of the cell (LUTHY; MATILE, 1984).

\section{Conclusions}

This study demonstrated that individual GSLs have different response to different cooking methods and cultivars. Although broccoli and cauliflower belong to the same Brassica family, fresh broccolis tend to lose the GSLs during blanching, sautéing and microwaving, while the GSLs of cauliflower, such as glucoraphanin, increased during blanching for $120 \mathrm{sec}$. It can be concluded that during the processing of vegetables, aliphatic GSL is generally more stable than indolyl GSL, thus indicating that the relative stabilities of individual GSLs may be a function of their respective chemical structures.

\section{Acknowledgements}

This research was financially supported by the Rural Development Administration (RDA, PJ0085942013).

\section{References}

BARBIERI, G. et al. Glucosinolates profile of Brassica rapa L. Subsp. Sylvestris L. Janch. var. esculenta Hort. Food Chemistry, v. 107, p. 1687-1691, 2008. http://dx.doi.org/10.1016/j. foodchem.2007.09.054

CARTEA, M. E. et al. Seasonal variation in glucosinolate content in Brassica oleracea crops grown in northwestern Spain. Phytochemistry, v. 69, p. 403-410, 2008. http://dx.doi.org/10.1016/j. phytochem.2007.08.014

CARTEA, M. E.; VELASCO, P. Glucosinolates in Brassica foods: Bioavailability in food and significance for human health. Phytochemistry, v. 7, p. 213-229, 2008. http://dx.doi.org/10.1007/ s11101-007-9072-2

CHEVOLLEAU, S. et al. Isolation and structure elucidation of a new thermal breakdown product of glucobrassicin, the parent indole glucosinolate. Journal of Agricultural and Food Chemistry, v. 50, p. 5185-5190, 2002. http://dx.doi.org/10.1021/jf020125i

CLARKE, D. B. Glucosinolates, structures and analysis in food. Analytical Methods, v. 2, p. 310-325, 2010. http://dx.doi. org/10.1039/B9AY00280D

DEKKER, M.; VERKERK, R.; JONGEN, W. M. F. Predictive modelling of health aspects in the food production chain: A case study on glucosinolates in cabbage. Trends in Food Science and Technology, v. 11, p. 174-181, 2000. http://dx.doi.org/10.1016/ S0924-2244(00)00062-5

HANSEN, M. et al. Chemical and sensory quality of broccoli (Brassica oleracea L. var. italica). Journal of Food Quality, v. 20, p. 441-459, 1997. http://dx.doi.org/10.1111/j.1745-4557.1997.tb00486.x

HORN, F. P. Cereals and Brassicas for forage. In: HEATH, M. E.; BARNES, R. F.; METCALFE, D. S. (Eds.). Forages: The Science of Grassland Agriculture. Iowa St. Univ. Press. Ames, 1985. p. 271-277.

INTERNATIONAL ORGANIZATION FOR STANDARDIZATION. ISO 9167: Rape seed determination of glucosinolates content. ISO, 1992. p. 1-9.

JEFFERY, E. H. et al. Variation in content of bioactive components in broccoli. Journal of Food Composition and Analysis, v. 16, p. 323-330, 2003. http://dx.doi.org/10.1016/S0889-1575(03)00045-0

JIA, C. G. et al. Effect of modified atmosphere packaging on visual quality and glucosinolates of broccoli florets. Food Chemistry, v. 114, p. 28-37, 2009. http://dx.doi.org/10.1016/j. foodchem.2008.09.009

JONES, R. B.; FARAGHER, J. D.; WINKLER, S. A. Review of the influence of postharvest treatments on quality and glucosinolate content in broccoli (Brassica oleracea var. italica) heads. Postharvest Biology and Technology, v. 41, p. 1-824, 2006. http://dx.doi. org/10.1016/j.postharvbio.2006.03.003

KELLY, P. J.; BONES, A.; ROSSITER, J. T. Sub-cellular immunolocalization of the glucosinolate sinigrin in seedlings of Brassica juncea. Planta, v. 206, p. 370-377, 1998. http://dx.doi. org/10.1007/s004250050412

KIM, S. J. et al. Glucosinolate in vegetative tissues and seeds of twelve cultivars of vegetable turnip rape (Brassica rapa L.). Soil Science and Plant Nutrition, v. 49, p. 337-346, 2002. http://dx.doi.org/10. 1080/00380768.2003.10410018

KIM, S. J.; JIN, S.; ISHII, G. Isolation and structure elucidation of 4-( $\beta$-D-Glucopyranosyldisul-fanyl)butyl glucosinolate from the leaves of Eruca sativa. Bioscience, Biotechnology, and Biochemistry, v. 71, p. 114-121, 2004. 
LI, T. et al. Research article Cruciferous vegetable intake is inversely associated with lung cancer risk among smokers: a case-control study. BMC Cancer, v. 10, p. 162, 2010. http://www.biomedcentral. com/1471-2407/10/162

LUTHY, B.; MATILE, P. The mustard oil bomb: rectified analysis of the subcellular organisation of the myrosinase system. Biochemie und Physiologie der Pflanzen, v. 179, p. 5-12, 1984. http://dx.doi. org/10.1016/S0015-3796(84)80059-1

MIGLIO, C. et al. Effects of different cooking methods on nutritional and physicochemical characteristics of selected vegetables. Journal of Agricultural and Food Chemistry, v. 56, p. 139-147, 2008. http:// dx.doi.org/10.1021/jf072304b
MITHEN, R. Glucosinolates and their degradation products. Advances in Botanical Research, v. 35, p. 213-262, 2001. http://dx.doi. org/10.1016/S0065-2296(01)35008-5

VERKERK, R. et al. Glucosinolates in Brassica vegetables: The influence of the food supply chain on intake, bioavailability and human health. Molecular Nutrition and Food Research, v. 53, p. S219-S265, 2009. http://dx.doi.org/10.1002/mnfr.200800065

VERKERK, R.; DEKKER, M.; JONGEN, W. M. F. Post-harvest increase of indolyl glucosinolates in response to chopping and storage of Brassica vegetables. Journal of the Science of Food and Agriculture, v. 81, p. 953-958, 2001. http://dx.doi.org/10.1002/ jsfa. 854 